\title{
The influence of wind on the work of the structure of columnar elements in reinforced concrete tall buildings
}

\author{
Roman Gąćkowski ${ }^{1}$
}

\begin{abstract}
:
The methods of designing tall buildings are based mainly on the analysis of the influence of aerodynamic effects on the work of cross-sections of individual reinforced concrete elements: columns, slabs and beams. On the example of a building on a rectangular plan with dimensions of $36 \times 60$ meters and a height of 400 meters, a detailed analysis of the operation of selected reinforced concrete columns was carried out. Six models of buildings, differing in the location of internal walls as the concentration of the load-bearing structure, were analyzed. Static calculations with aerodynamic simulation were performed in Autodesk Robot Structural Analysis Professional 2022. On this basis, the final results were prepared and the most optimal layout of walls in tall buildings was selected.
\end{abstract}

\section{KEYWORDS}

tall buildings; wind load; aerodynamic simulations

\section{Introduction}

Already in the years 1884-1885, the eleven-story Home Insurance Building was constructed in Chicago, designed by William LeBaron Jenney as an iron and steel structure. The building was demolished in 1931 (Fig. 1a).

In 1890-1994, attempts were made in Chicago to build the Reliance Building of considerable height (Fig. 1b). The building had 14 floors and was designed by Daniel Burnham. Restored in 1995 and now houses the Burnham Hotel. The first skyscraper of the Chrysler Building was built in New York in the first half of the 20th century, with a total height of $318.9 \mathrm{~m}$ and 77 floors (Fig. 1c). For this purpose, the skeleton system of the building was used, consisting of load-bearing elements (columns, beams, ceilings, internal walls and bracings), which was supposed to transfer permanent and variable loads (functional and climatic). The opening of the building took place in May 1930. A year later, the construction of the Empire State Building began, a skyscraper with a total height of $443.2 \mathrm{~m}$ (Fig. 1d).

The twentieth and twenty-first centuries are the time when the world-famous skyscrapers were built. The currently tallest Burj Khalifa building is located in Dubai, United Arab Emirates (Fig. 2a). Construction began on September 21, 2004 and was completed on August 16, 2009. The building is 827.9 meters high and has 163 floors.

In the Pudong district of Shanghai, China, there is the second tallest Shanghai Tower, 632 meters high. Construction started on November 29, 2008 and was completed in 2015 (Fig. 2b)

In the years 2004-2011, the Abraj al-Bayt hotel complex was built in Mecca, Saudi Arabia, the height of which is 559 meters (Fig. 2c). In the following years 2010-2016, Ping An Finance Center was built in Shenzhen, China, a building with a height of 599 meters. (Fig. 2d). 
From 2011 to 2017, the 129-story, 555.7-meter-high Lotte World Tower was built in Seoul, South Korea (Fig. 2e).
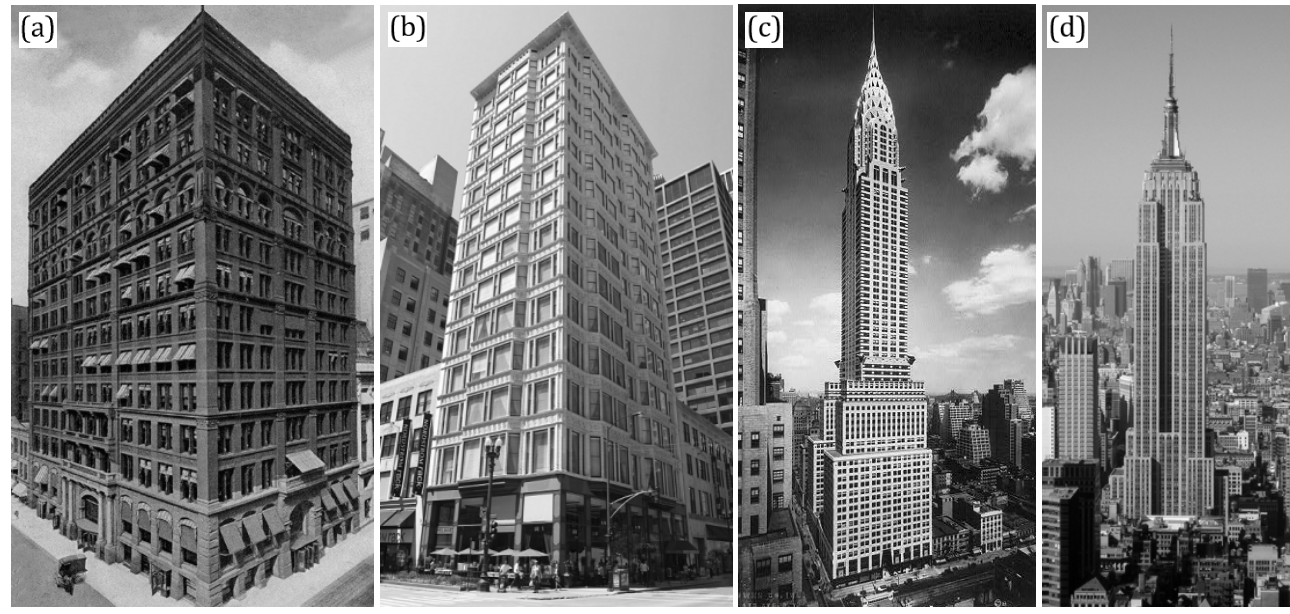

Fig. 1. First tall buildings: a) Home Insurance Building in Chicago [1]; b) Reliance Building in Chicago [2]; c) Chrysler Building in New York [3]; d) Empire State Building in New York [4]
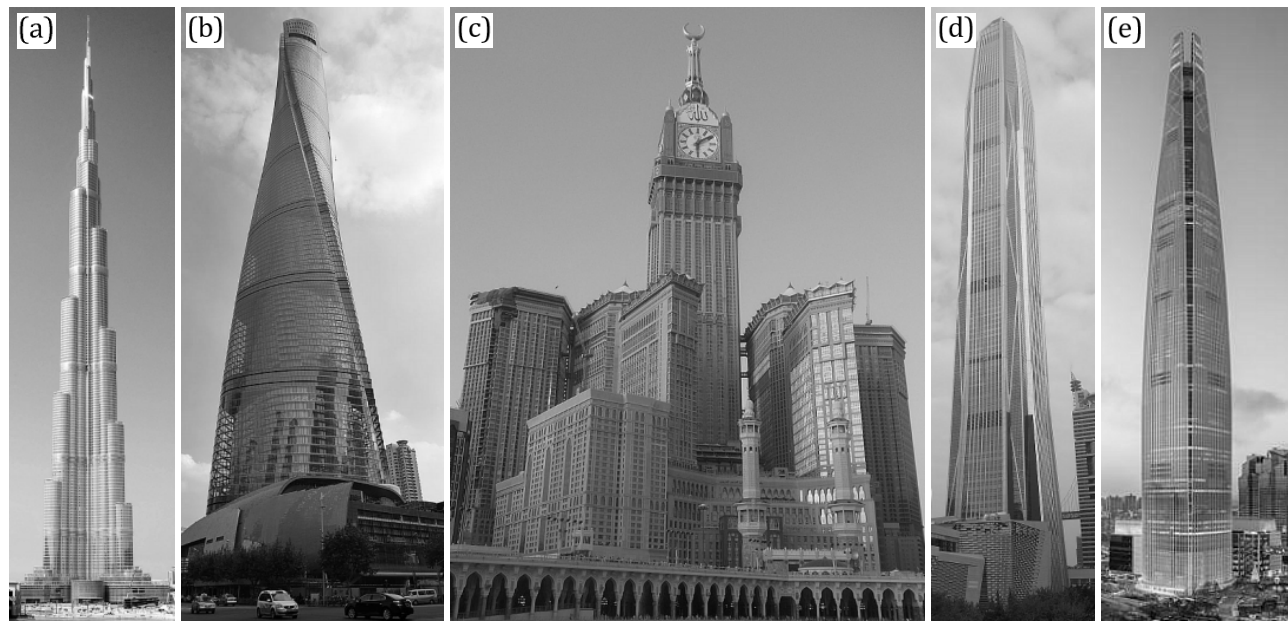

Fig. 2. The tallest buildings in the world: a) Burj Khalifa, Dubai - United Arab Emirates [5]; b) Reliance Building in Chicago [6]; c) Abraj al-Bajt hotel complex [7]; d) Ping An Finance Centre [8]; e) Lotte World Tower [9]

\section{Characteristics of the analyzed building}

The building was analyzed on a rectangular plan with dimensions of $36 \times 60$ meters and a height of 400 meters. The building has 100 storeys with a height of 4.0 meters each. The loadbearing elements are reinforced concrete columns, beams and slabs, which are ceilings with a thickness of $22 \mathrm{~cm}$. The cross-section of the poles was diversified, i.e.

- $80 \times 80 \mathrm{~cm}$ columns are adopted from the $1 \mathrm{st}$ to the 25 th storeys,

- $70 \times 70 \mathrm{~cm}$ columns are adopted from the 26th to the 50th storeys,

- $60 \times 60 \mathrm{~cm}$ columns are adopted from the $51 \mathrm{st}$ to the 75 th storeys,

- $50 \times 50 \mathrm{~cm}$ columns were adopted from 76 to 100 storeys. 
Reinforced concrete elements are made of concrete class C35/45 and reinforcing steel class "C" B500SP EPSTAL. The building is in the first wind load zone and the second snow load zone. According to [10] Tables 6.1 and 6.2, the building use category was assumed as C2, and on this basis the service load use equal to $4.0 \mathrm{kN} / \mathrm{m}^{2}$.

The building is founded on a reinforced concrete grate connected monolithically with the foundation slab. The elements of the building bracing are $25 \mathrm{~cm}$ thick reinforced concrete walls arranged according to a specific scheme presented in Figure 3. The basic (base) system is a floor without internal FP-1 stiffening walls. The second variant of the building cross-section is FP-2 with a reinforced concrete core located in the central part of the building. Schemes FP-3 and FP-4 are the placement of reinforced concrete walls along the shorter and longer side of the building, respectively. The FP-5 diagram is a combination of the FP-3 and FP-4 diagrams. An alternative solution to bracing the building is to use reinforced concrete walls in the corners of the building - diagram FP-6. Six characteristic columns marked in Figure 3 as C- $1 \div \mathrm{C}-6$ were analyzed.
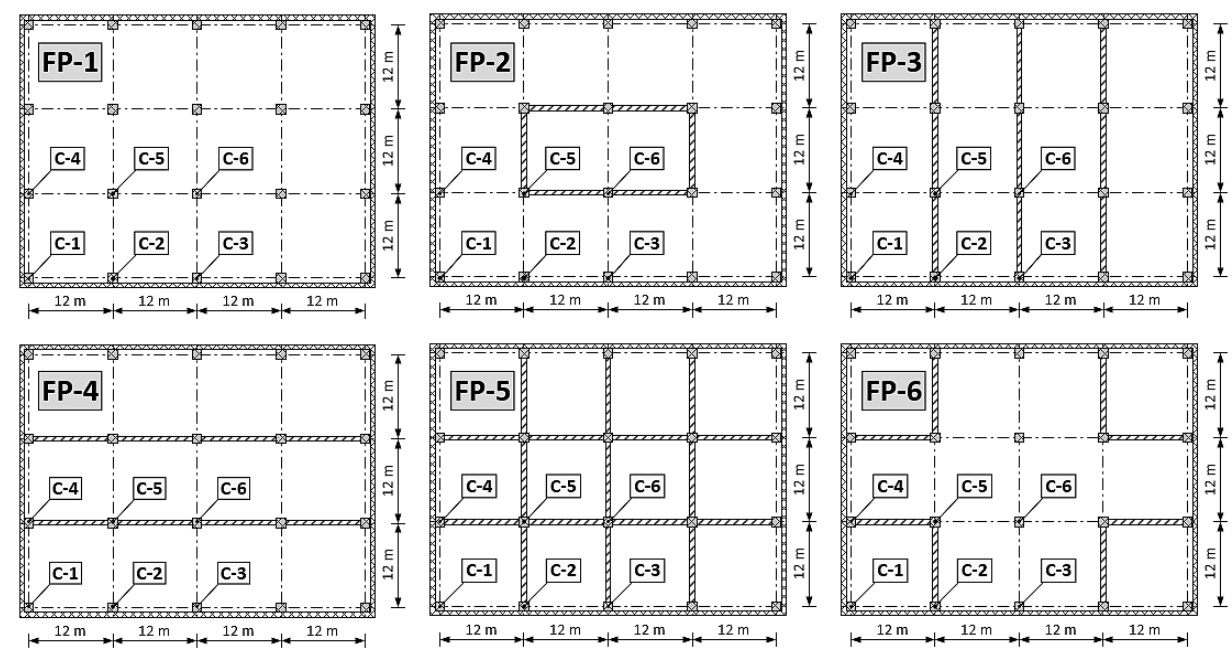

Fig. 3. Horizontal projections of the structural systems of a tall building: FP-1 basic structural system without internal walls; FP-2 structural system of the ceiling with a central reinforced concrete core; FP-3 structural system of the ceiling with transverse walls (along the shorter edge of the building); FP-4 structural system of the ceiling with longitudinal walls (along the longer edge of the building); FP-5 structural system of the ceiling with transverse and longitudinal walls; FP-6 structural system of the ceiling with corner walls

\section{Analysis of the building's structural system}

The building was modeled in Autodesk Robot Structural Analysis Professional 2022 as a shell model with bar elements of a beam and columns. The shell elements are external and internal walls and ceilings. Composite Delaunay meshing was used in static calculations. The view of the model is presented in Figure 4. Wrza with the division into elements and nodes of the separated columns C- 1 to C- 6 . The permanent and service load applied to the ceilings were assumed to be surface loads. As the wind load, the aerodynamic simulation for the first wind zone was adopted, in which the wind affects the building from all sides. The self-weight of the structure elements was automatically generated in the program.

The analysis of the building structure was carried out for six variants (Fig. 3). The analysis compared the axial forces FX in the separated columns C- 1 to C- 6 in the building and the total deflection of the columns in characteristic sections. The characteristic sections are the places where the cross-sections of the columns change at the level of $\pm 0.0 ;+100 \mathrm{~m} ;+200 \mathrm{~m} ;+300 \mathrm{~m}$; $+400 \mathrm{~m}$. 


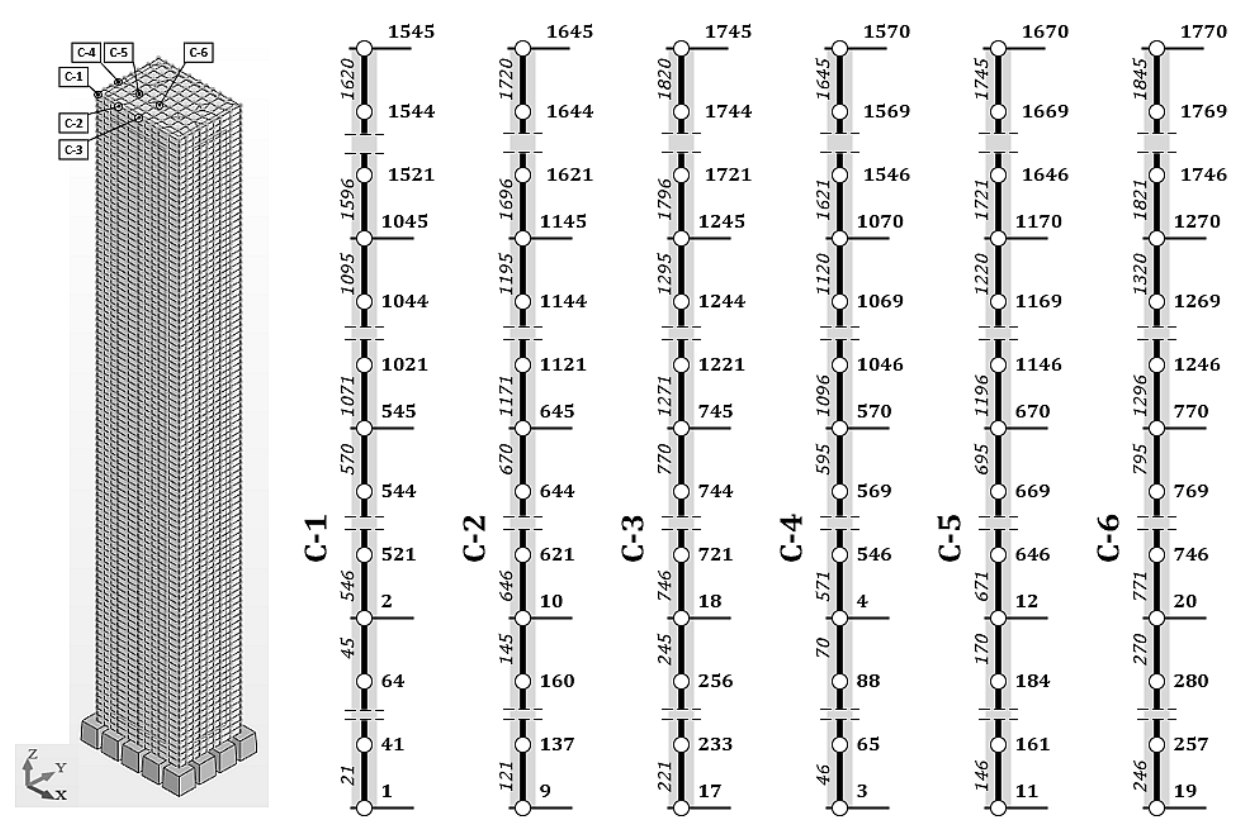

Fig. 4. Calculation model of a tall building. Place of the analyzed C-1 $\div$ C- 6 reinforced concrete columns

Table 1

Calculation results of axial forces in individual C-1 $\div$ C -6 columns

\begin{tabular}{|c|c|c|c|c|c|c|c|c|c|c|}
\hline \multicolumn{5}{|c|}{ Columns } & \multicolumn{6}{|c|}{$\begin{array}{c}\text { Axial force } \\
\text { FX [kN] }\end{array}$} \\
\hline $\begin{array}{c}\text { Bottom } \\
\text { node }\end{array}$ & $\begin{array}{l}\text { No of } \\
\text { bars }\end{array}$ & $\begin{array}{c}\text { Top } \\
\text { node }\end{array}$ & $\begin{array}{c}\text { No of } \\
\text { column }\end{array}$ & $\begin{array}{c}\text { Cross section } \\
{[\mathrm{cm}]}\end{array}$ & PF-1 & PF-2 & PF-3 & PF-4 & PF-5 & PF-6 \\
\hline 1544 & 1620 & 1545 & \multirow{5}{*}{ C-1 } & $50 \times 50$ & -84.78 & -2.37 & 33.65 & 17046,00 & 20.64 & -146.58 \\
\hline 1045 & 1596 & 1521 & & $60 \times 60$ & 4983.53 & 3535.41 & 3664.44 & 3821.02 & 2982.48 & 3873.85 \\
\hline 545 & 1071 & 1021 & & $70 \times 70$ & 13850.11 & 10056.06 & 10494.88 & 10979.83 & 8597.82 & 10526.15 \\
\hline 2 & 546 & 521 & & $80 \times 80$ & 26752.65 & 20060.14 & 21148.71 & 22155.89 & 17475.5 & 20629.58 \\
\hline 1 & 21 & 41 & & $80 \times 80$ & 103491.52 & 70774.56 & 75305.95 & 85103.77 & 64032.91 & 76822.94 \\
\hline 1644 & 1720 & 1645 & \multirow{5}{*}{ C-2 } & $50 \times 50$ & 86.04 & 56.49 & 25.72 & 72.35 & 46.54 & -20.27 \\
\hline 1145 & 1696 & 1621 & & $60 \times 60$ & 4932.22 & 3484.84 & 3583.01 & 3784.23 & 2915.08 & 3764.38 \\
\hline 645 & 1171 & 1121 & & $70 \times 70$ & 13794.2 & 9928.44 & 10265.34 & 10910.21 & 8462.03 & 10359.52 \\
\hline 10 & 646 & 621 & & $80 \times 80$ & 26815.28 & 19897.02 & 20744.94 & 22100.67 & 17269.59 & 20463,00 \\
\hline 9 & 121 & 137 & & $80 \times 80$ & 96825.37 & 69922,00 & 78153.86 & 82319.67 & 66759.81 & 86433.92 \\
\hline 1744 & 1820 & 1745 & \multirow{5}{*}{ C-3 } & $50 \times 50$ & 94.04 & 51.59 & 44261,00 & 70.86 & 35.33 & 107.85 \\
\hline 1245 & 1796 & 1721 & & $60 \times 60$ & 4958.59 & 3500.04 & 3583.07 & 3790.21 & 2925.49 & 3785.13 \\
\hline 745 & 1271 & 1221 & & $70 \times 70$ & 13934.32 & 10010.49 & 10281.2 & 10963.54 & 8507.33 & 10565.52 \\
\hline 18 & 746 & 721 & & $80 \times 80$ & 27255.66 & 20158.07 & 20845.74 & 22280.58 & 17434.01 & 21075.51 \\
\hline 17 & 221 & 233 & & $80 \times 80$ & 99925.99 & 75557.72 & 79873.51 & 83907.94 & 70921.6 & 76168.14 \\
\hline 1569 & 1645 & 1570 & \multirow{5}{*}{ C-4 } & $50 \times 50$ & 83.4 & 26.59 & 32.5 & 18.16 & 42.8 & -22.18 \\
\hline 1070 & 1621 & 1546 & & $60 \times 60$ & 4936.27 & 3470.04 & 3609.8 & 3732.32 & 2912.79 & 3761.29 \\
\hline 570 & 1096 & 1046 & & $70 \times 70$ & 13839.98 & 9884.46 & 10377.85 & 10680.04 & 8377.12 & 10345.16 \\
\hline 4 & 571 & 546 & & $80 \times 80$ & 26953.15 & 19771.65 & 21003.51 & 21619.08 & 17075.55 & 20423.16 \\
\hline 3 & 46 & 65 & & $80 \times 80$ & 95338.92 & 69962.67 & 75215.45 & 84594.8 & 64572.84 & 87845.7 \\
\hline 1669 & 1745 & 1670 & \multirow{5}{*}{ C-5 } & $50 \times 50$ & 468.69 & 100.22 & -84.73 & -154.94 & -173.59 & -69073.86 \\
\hline 1170 & 1721 & 1646 & & $60 \times 60$ & 18710.8 & 5307.08 & 3611.07 & 3800.19 & 2934.78 & -4582.6 \\
\hline 670 & 1196 & 1146 & & $70 \times 70$ & 48030.94 & 15296.75 & 10341.52 & 10881.05 & 8360.06 & 23991.58 \\
\hline 12 & 671 & 646 & & $80 \times 80$ & 95798.2 & 31231.62 & 21119.27 & 22096.78 & 16955.07 & 63705.17 \\
\hline 11 & 146 & 161 & & $80 \times 80$ & 166587.92 & 110692.89 & 81903.77 & 84732.19 & 69603.71 & 129083.83 \\
\hline 1769 & 1845 & 1770 & \multirow{5}{*}{ C-6 } & $50 \times 50$ & 600.79 & -122.26 & -160.31 & -155.15 & -184.34 & -172.48 \\
\hline 1270 & 1821 & 1746 & & $60 \times 60$ & 23777.49 & 5170.69 & 3603.29 & 3754.3 & 2954.63 & 9372.99 \\
\hline 770 & 1296 & 1246 & & $70 \times 70$ & 61976.99 & 15106.07 & 10337.16 & 10973.04 & 8404.4 & 33246.76 \\
\hline 20 & 771 & 746 & & $80 \times 80$ & 124505.68 & 31107,00 & 21160.5 & 22266.83 & 17121.42 & \begin{tabular}{|l|l|}
74973.04 \\
\end{tabular} \\
\hline 19 & 246 & 257 & & $80 \times 80$ & 208700.23 & 106205.27 & 82576.65 & 87618.88 & 72162.6 & 141346.87 \\
\hline
\end{tabular}


Table 2

Results of deformation of tall columns depending on the analyzed model

\begin{tabular}{|c|c|c|c|c|c|c|c|c|c|c|c|}
\hline \multicolumn{5}{|c|}{ Columns } & \multicolumn{6}{|c|}{$\begin{array}{l}\text { Column top deformation } \\
\mathbf{u}[\mathrm{cm}]\end{array}$} & \multirow{2}{*}{\begin{tabular}{|c|}
$\begin{array}{c}\text { Considered } \\
\text { height storeys }\end{array}$ \\
H [m]
\end{tabular}} \\
\hline $\begin{array}{c}\text { Bottom } \\
\text { node }\end{array}$ & $\begin{array}{l}\text { No of } \\
\text { bars }\end{array}$ & $\begin{array}{c}\text { Top } \\
\text { node }\end{array}$ & \begin{tabular}{|c|}
$\begin{array}{c}\text { No of } \\
\text { column }\end{array}$ \\
\end{tabular} & $\begin{array}{c}\text { Cross section } \\
{[\mathrm{cm}]}\end{array}$ & PF-1 & PF-2 & PF-3 & PF-4 & PF-5 & PF-6 & \\
\hline 1544 & 1620 & 1545 & \multirow{5}{*}{ C-1 } & $50 \times 50$ & 42.4 & 35.7 & 30.0 & 40.6 & 29.9 & 31.5 & 400 \\
\hline 1045 & 1596 & 1521 & & $60 \times 60$ & 35.0 & 27.8 & 25.3 & 31.5 & 23.4 & 26.0 & 300 \\
\hline 545 & 1071 & 1021 & & $70 \times 70$ & 25.6 & 19.0 & 19.6 & 21.3 & 16.6 & 19.6 & 200 \\
\hline 2 & 546 & 521 & & $80 \times 80$ & 14.5 & 10.9 & 11.6 & 12.3 & 9.7 & 11.6 & 100 \\
\hline 1 & 21 & 41 & & $80 \times 80$ & 0.0 & 0.0 & 0.0 & 0.0 & 0.0 & 0.0 & 0 \\
\hline 1644 & 1720 & 1645 & \multirow{5}{*}{ C-2 } & $50 \times 50$ & 42.8 & 35.8 & 30.5 & 40.7 & 30.0 & 31.8 & 400 \\
\hline 1145 & 1696 & 1621 & & $60 \times 60$ & 35.5 & 28.1 & 25.8 & 31.6 & 23.5 & 26.2 & 300 \\
\hline 645 & 1171 & 1121 & & $70 \times 70$ & 26.1 & 19.3 & 19.7 & 21.5 & 16.7 & 19.8 & 200 \\
\hline 10 & 646 & 621 & & $80 \times 80$ & 14.8 & 11.1 & 11.8 & 12.4 & 9.9 & 11.8 & 100 \\
\hline 9 & 121 & 137 & & $80 \times 80$ & 0.0 & 0.0 & 0.0 & 0.0 & 0.0 & 0.0 & 0 \\
\hline 1744 & 1820 & 1745 & \multirow{5}{*}{ C-3 } & $50 \times 50$ & 43.2 & 36.0 & 31.0 & 40.8 & 30.1 & 31.9 & 400 \\
\hline 1245 & 1796 & 1721 & & $60 \times 60$ & 36.1 & 28.3 & 26.3 & 31.8 & 23.6 & 26.5 & 300 \\
\hline 745 & 1271 & 1221 & & $70 \times 70$ & 26.7 & 19.5 & 20.2 & 21.7 & 16.9 & 20.1 & 200 \\
\hline 18 & 746 & 721 & & $80 \times 80$ & 15.2 & 11.3 & 11.9 & 12.5 & 10.0 & 12.0 & 100 \\
\hline 17 & 221 & 233 & & $80 \times 80$ & 0.0 & 0.0 & 0.0 & 0.0 & 0.0 & 0.0 & 0 \\
\hline 1569 & 1645 & 1570 & \multirow{5}{*}{ C-4 } & $50 \times 50$ & 43.4 & 36.5 & 30.5 & 41.6 & 30.6 & 32.3 & 400 \\
\hline 1070 & 1621 & 1546 & & $60 \times 60$ & 36.1 & 28.8 & 25.9 & 32.6 & 24.2 & 26.8 & 300 \\
\hline 570 & 1096 & 1046 & & $70 \times 70$ & 26.6 & 20.0 & 20.1 & 22.6 & 17.0 & 20.2 & 200 \\
\hline 4 & 571 & 546 & & $80 \times 80$ & 15.0 & 11.1 & 11.9 & 12.4 & 9.7 & 11.8 & 100 \\
\hline 3 & 46 & 65 & & $80 \times 80$ & 0.0 & 0.0 & 0.0 & 0.0 & 0.0 & 0.0 & 0 \\
\hline 1669 & 1745 & 1670 & \multirow{5}{*}{ C-5 } & $50 \times 50$ & 112.6 & 45.7 & 31.2 & 41.8 & 30.7 & 34.4 & 400 \\
\hline 1170 & 1721 & 1646 & & $60 \times 60$ & 102.6 & 38.9 & 26.5 & 32.9 & 24.4 & 60.7 & 300 \\
\hline 670 & 1196 & 1146 & & $70 \times 70$ & 80.8 & 30.0 & 20.3 & 22.9 & 17.1 & 54.5 & 200 \\
\hline 12 & 671 & 646 & & $80 \times 80$ & 47.0 & 17.6 & 12.0 & 12.6 & 9.7 & 34.1 & 100 \\
\hline 11 & 146 & 161 & & $80 \times 80$ & 0.0 & 0.0 & 0.0 & 0.0 & 0.0 & 0.0 & 0 \\
\hline 1769 & 1845 & 1770 & \multirow{5}{*}{ C-6 } & $50 \times 50$ & 143.3 & 45.9 & 31.6 & 41.9 & 30.8 & 81.0 & 400 \\
\hline 1270 & 1821 & 1746 & & $60 \times 60$ & 131.4 & 39.1 & 26.9 & 33.1 & 24.5 & 77.2 & 300 \\
\hline 770 & 1296 & 1246 & & $70 \times 70$ & 103.9 & 30.3 & 20.7 & 23.1 & 17.3 & 63.6 & 200 \\
\hline 20 & 771 & 746 & & $80 \times 80$ & 60.3 & 17.8 & 12.1 & 12.8 & 9.9 & 38.6 & 100 \\
\hline 19 & 246 & 257 & & $80 \times 80$ & 0.0 & 0.0 & 0.0 & 0.0 & 0.0 & 0.0 & 0 \\
\hline
\end{tabular}
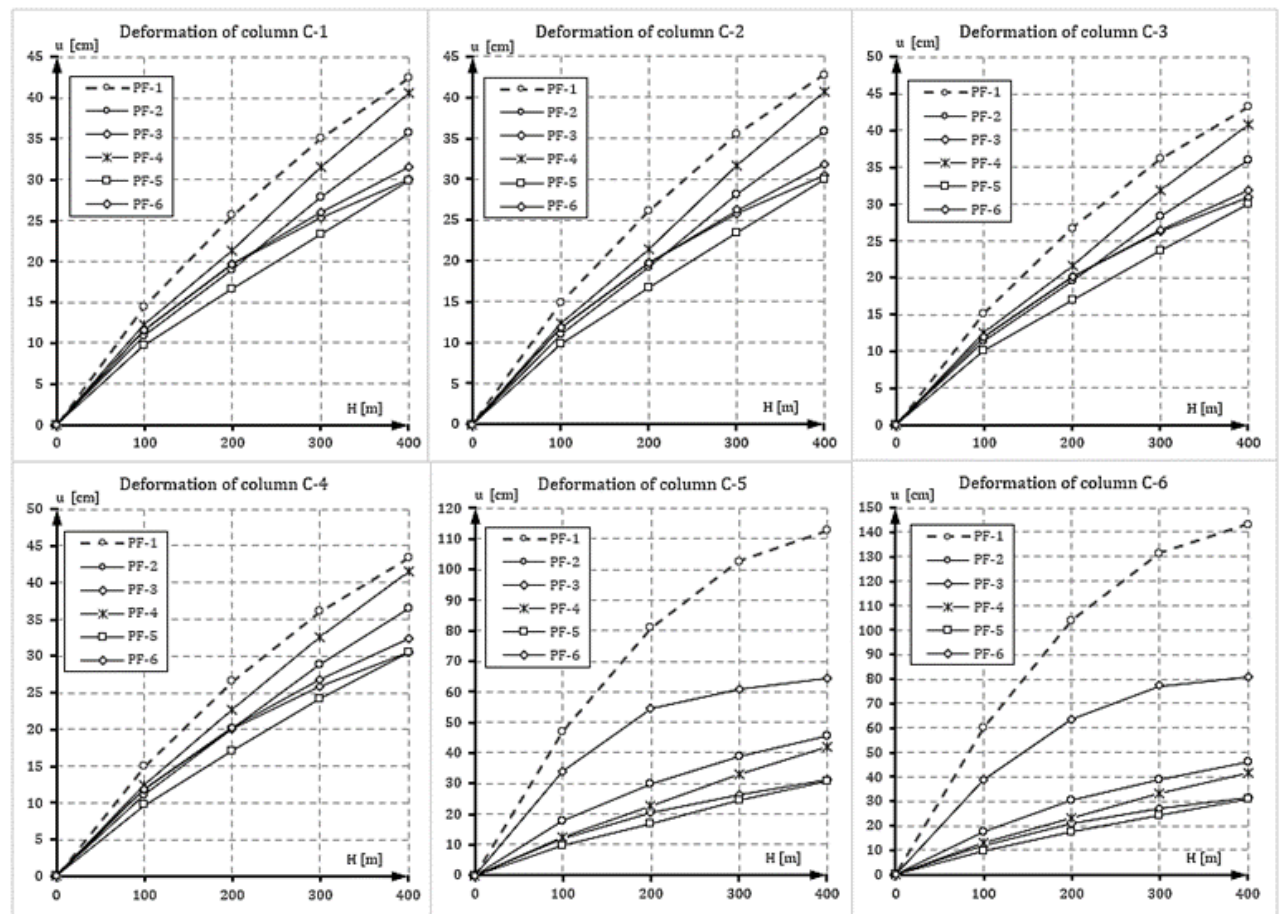

Fig. 5. Graphical presentation of the results of deformation tall building's columns, depending on the analyzed model 
The results of the analysis are presented in Tables 1 and 2 and graphically in Figures 5, 6. Based on the values of the axial forces FX, it is possible to estimate the optimal cross-section of the columns on individual levels. Knowing the deflection of the tops of the columns in the building, it is possible to assume the optimal arrangement of bracings of internal walls in the building. The permissible deflection of tall buildings in accordance with [11] is $\mathrm{H} / 500$, which for the analyzed object is $\mathbf{u}_{\mathrm{lim}}=\mathbf{4 0 0 0 0} / \mathbf{5 0 0}=\mathbf{8 0} \mathbf{c m}$.

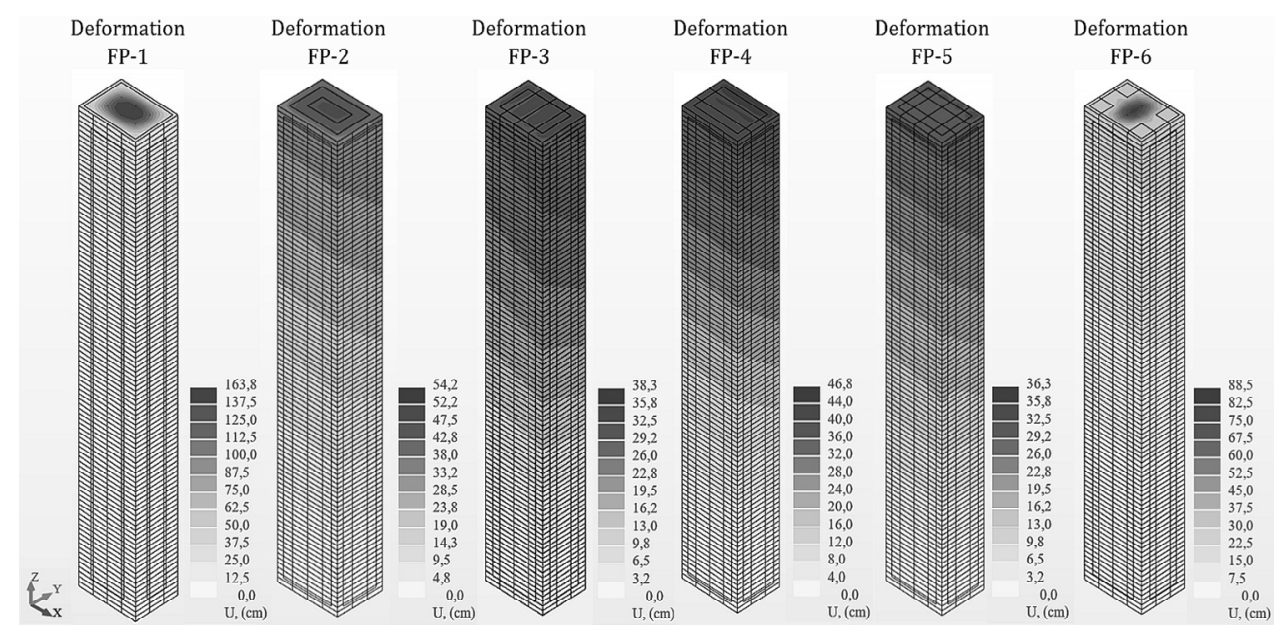

Fig. 6. The results of deformation of the tall building depending on the analyzed model

Table 3

The results of deformation of $\mathrm{C}-1 \div \mathrm{C}-6$ columns in tall buildings are presented in [\%] depending on the arrangement of internal walls (Fig. 3)

\begin{tabular}{|c|c|c|c|c|c|c|c|}
\hline \multirow{2}{*}{\multicolumn{2}{|c|}{$\begin{array}{c}\text { No } \\
\text { of column }\end{array}$}} & \multicolumn{5}{|c|}{$\begin{array}{c}\text { Column top deformation } \\
\delta=\mathrm{u} / \mathrm{u}_{\mathrm{lim}}[\%]\end{array}$} & \multirow{2}{*}{$\begin{array}{c}\mathrm{u}_{\mathrm{lim}}=80 \\
\mathrm{~cm}\end{array}$} \\
\hline & & PF-1 & PF-2 & PF-3 & PF-4 & PF-5 & \\
\hline \multirow{3}{*}{$\begin{array}{c}\text { external } \\
\text { colums }\end{array}$} & $\mathrm{C}-1$ & 53,0 & 44,6 & 37,5 & 50,8 & 37,4 & 39,4 \\
\hline & $\mathrm{C}-2$ & 53,5 & 44,8 & 38,1 & 50,9 & 37,5 & 39,8 \\
\hline & $\mathrm{C}-3$ & 54,0 & 45,0 & 38,8 & 51,0 & 37,6 & 39,9 \\
\hline \multirow{3}{*}{$\begin{array}{l}\text { internal } \\
\text { colums }\end{array}$} & C-4 & 54,3 & 45,6 & 38,1 & 52,0 & 38,3 & 40,4 \\
\hline & C-5 & 140,8 & 57,1 & 39,0 & 52,3 & 38,4 & 80,5 \\
\hline & C-6 & 179,1 & 57,4 & 39,5 & 52,4 & 38,5 & 101,3 \\
\hline
\end{tabular}

\section{Conclusion}

The main aim of the article was to show the influence of the arrangement of internal walls in the building (Fig. 3) on the size of internal forces in selected columns (Fig. 4) according to ULS and deformation of these elements (Fig. 6) according to SLS. The geometric parameters of the building (width, length, height and number of storeys) have been selected in accordance with the guidelines applicable to the design of high-rise buildings. The location of the building was selected for the first wind load zone and the second snow load zone.

The analysis of the building's operation (mainly columnar elements), in which a detailed areodynamic simulation in all directions was taken into account, showed:

- The share of columns in operation of the entire building is dominant and the values of the compressive axial forces and the final deformation depend on the location of the columns (Fig. 4) and the dimensions of the columns on individual storeys directly depend on the arrangement of internal walls in the building (Fig. 3). The C-6 splitter in the PF-1 diagram is the most loaded and the lowest axial force FX is in the C-1 column in the PF-5 diagram (Table 1). 
- The arrangement of internal walls, constituting the bracing of the entire building, has a significant impact on the operation of the entire tall building. In the absence of internal walls (FP-1 diagram), the value of axial forces FX in internal C-4 $\div$ C- 6 columns increases from $\mathbf{1 9 6 . 5}$ to $\mathbf{2 8 9 . 2 \%}$ compared to systems with internal walls (FP-2 $\div \mathrm{FP}-6$ diagrams). In the $\mathrm{C}-1 \div \mathrm{C}-3$ external columns it increases from $\mathbf{1 1 9 . 1}$ to $\mathbf{1 4 0 . 9 \%}$.

- Due to the arrangement of internal walls in the building, the optimal solution is to use walls in the longitudinal and transverse directions (FP-5 diagram). The lack of internal walls (PF-1 diagram) and the use of walls only in the corners of tall buildings (FP-6 diagram) is an insufficient solution for the operation of the structure. Removal of transverse or longitudinal walls increases the value of forces in individual columns.

- The displacement of the top of the C- 6 internal column in the PF-1 diagram is exceeded by $\mathbf{1 7 9 . 1 \%}$, which suggests an insufficient solution due to the lack of bracing of the building with internal walls (Table 3).

- The optimal solution is the PF-5 scheme with the longitudinal and transverse arrangement of internal walls, in which the maximum displacements constitute $37.6 \%$ of the permissible value for the $\mathrm{C}-3$ outer column and $\mathbf{3 8 . 5 \%}$ of the permissible value for the C- 6 inner column (Table 3).

In conclusion, constructions of the column and beam skeletal systems, which are devoid of internal walls constituting the concentration of the entire high building, should not be used.

\section{References}

[1] https://images.skyscrapercenter.com/building/homeinsurancebuilding_ext-color_pubdom.png

[2] https://s3.amazonaws.com/architecture-org/files/buildings/wide_lrg_reliance-building-02.jpg

[3] https://upload.wikimedia.org/wikipedia/commons/a/a9/Chrysler_Building\%2C_NY.jpg

[4] https://upload.wikimedia.org/wikipedia/commons/c/c7/Empire_State_Building_from_the_Top_of_the_Rock.jpg

[5] https://upload.wikimedia.org/wikipedia/pl/2/2e/Burj_Khalifa\%2C_2009.jpg

[6] https://upload.wikimedia.org/wikipedia/commons/thumb/3/32/Shanghai_Tower_2015.jpg/800px-Shanghai Tower_2015.jpg

[7] https://upload.wikimedia.org/wikipedia/pl/thumb/f/f4/Abraj-al-Bait-Towers.JPG/800px-Abraj-al-Bait-Tow ers.JPG

[8] https://upload.wikimedia.org/wikipedia/commons/0/0f/\%E5\%B9\%B3\%E5\%AE\%89\%E9\%87\%91\%E8\%9 E\%8D\%E4\%B8\%AD\%E5\%BF\%83_2019-12-23.jpg

[9] http://nowoczesna-architektura.pl/sites/default/files/styles/900x600/public/slider/1_lotte_world_tower.jpg ?itok=sW8kmpio

[10] PN-EN 1991-1-1:2004. Eurokod 1: Oddziaływania na konstrukcje. Część 1-1: Oddziaływania ogólne. Ciężar objętościowy, ciężar własny, obciążenia użytkowe w budynkach.

[11] Pawłowski A.Z., Cała I., Budynki wysokie, Oficyna Wydawnicza Politechniki Warszawskiej, Warszawa 2013.

\section{Wpływ oddziaływań wiatru na pracę konstrukcji elementów słupowych w żelbetowych budynkach wysokich}

\section{STRESZCZENIE:}

Sposoby projektowania budynków wysokich opierają się głównie na analizie wpływu oddziaływań aerodynamicznych na pracę przekrojów poprzecznych poszczególnych elementów żelbetowych: słupów, płyt i belek. Na przykładzie budynku na rzucie prostokąta o wymiarach $36 \times 60$ metrów i wysokości 400 metrów przeprowadzono szczegółową analize pracy wybranych żelbetowych słupów. Analizie poddano 6 modeli budynków różniących się między sobą położeniem ścian wewnętrznych jako stężenia konstrukcji nośnej. Obliczenia statyczne wraz z symulacją aerodynamiczną wykonano w programie Autodesk Robot Structural Analysis Professional 2022. Na tej podstawie opracowano wyniki końcowe i wybrano najbardziej optymalny układ ścian w budynkach wysokich.

SŁOWA KLUCZOWE:

budynki wysokie; obciążenia wiatrem; symulacje aerodynamiczne 